\title{
Hazard Analysis of Domestic Ground Water Sources in Abubakar Tafawa Balewa University (ATBU, Yelwa Campus), Bauchi Nigeria
}

\author{
Ndububa Olufunmilayo", Nwafor Izuchukwu \\ Department of Civil Engineering, Abubakar Tafawa Balewa University, Nigeria
}

Copyright (C) 2015 by authors, all rights reserved. Authors agree that this article remains permanently open access under the terms of the Creative Commons Attribution License 4.0 International License

\begin{abstract}
Ground water supply for domestic use accounts for a large proportion of domestic water use in the Abubakar Tafawa Balewa University (ATBU) (Yelwa Campus). This implies that the sanitary quality of groundwater for domestic use in the institution is of paramount importance for the well being of the end users. The water quality of domestic groundwater sources in ATBU campus was analyzed by determining their physical, chemical and biological characteristics and 'Hazard Analysis' of the ground water sources for domestic use was determined based on the Water Safety Plan concept. Results obtained were compared to international water quality standards to identify the potential risks to various parameters and identify priority interventions to eliminate/ reduce contamination levels in the sources of water. Laboratory results showed that samples from a water source had Total Dissolved Solids (TDS) and Conductivity levels higher than values stated in the Drinking Water Standards. All other samples met the World Health Organization (WHO) and Nigerian Industrial Standards (NIS) guidelines for drinking water in terms of the physiochemical requirements. Total bacterial count obtained from two of the water sources was linked to the method of abstract of water. Results from the Hazard Analysis showed that five water sources monitored met all the requirements for drinking water quality, corrective measured were proffered for three sources on Well/ Borehole head tightness.
\end{abstract}

Keywords Contamination, Pollution, Risk, Hazard, Sanitary

\section{Introduction}

Pure water does not generally occur in nature. This is because all natural water whether surface, precipitation or ground all contain dissolved solids and gases as well as suspended matter. The quality and quantity of these constituents depends on geologic and environmental factors, which continuously change as a result of the reaction of water with contact media and human activities. These activities especially human can adversely affect the groundwater resources. Ground water is polluted by runoff from fertilized fields, livestock areas, abandoned mines, salted roads and industrial areas. Other sources of groundwater pollution include leachate from refuse dumps, gasoline leakage into ground water from underground storage tanks, waste water disposal systems. The effect of these pollutants in water can give rise to life threatening diseases especially diseases associated with unimproved domestic water supply, these diseases are water borne, water washed, water related insect vector etc.

Water-related diseases remain one of the major health concerns in the world, which are largely derived from poor water quality and sanitation, these account for about 3 million deaths and contributes to about 62 million 'Disability Adjusted Life Years' annually [1]. This health burden is primarily borne by the populations in developing countries and by children. Currently, it is estimated that 663 million people worldwide still use unimproved drinking water sources, including unprotected wells, springs and surface water. The majority of the people using unimproved drinking water sources live in sub-Saharan Africa, [2]. The use of unimproved drinking water sources is a major challenge coupled with uncontrolled siting of latrines. Sanitation facilities which are appropriate to meet the needs and demands of communities at affordable cost both at construction and operation and maintenance for end users are viable options to the control of contamination of domestic water sources. [3]. Factors such as the presence of uncapped wells and poor sanitary completion of the wells are as important as subsurface leaching of microbial contamination [4]. Around the world, especially in developing countries, there are billions of people who lack any hygienic and acceptable methods of excreta disposal [5].

\subsection{Problem Statement}

Ground water supply for domestic use accounts for a large proportion of domestic water use in the Abubakar Tafawa Balewa University (ATBU) (Yelwa Campus). The various 
On-site sanitation (excreta disposal) systems in the school constitute a major concern with regards to the quality of groundwater used for domestic purposes in the campus. Leachate has been identified as one of the source of ground water pollution, [6], leachate is the liquid formed when water passes through the waste in landfill sites and are regarded as highly polluted waste waters. They can contain large amount of organic matter as well as ammonium and nitrogeneous compounds, heavy metals, chlorinated organic and inorganic salts [7]. These compounds percolate deep through soil and subsoil causing extensive pollution of streams, creeks and water wells, if they are not properly collected, treated and safely disposed. Direct ingress of leachate affects the quality of groundwater [8]. The possibility of chemical substances and micro-biological organisms contaminating groundwater sources which poses health hazard to the community has prompted this research to assess the situation on the University campus.

\subsection{Objective of the Study}

The water quality of domestic groundwater sources in ATBU campus was analyzed by determining their physical, chemical and biological characteristics. Results obtained were compared to international water quality standards to identify the potential risks to various parameters and identify priority interventions to eliminate/ reduce contamination levels in the sources of water.

\subsection{The Study Area}

Abubakar Tafawa Balewa University (ATBU) (Yelwa Campus) is located in Yelwa town of Bauchi Local Government Area in Bauchi State of Nigeria with coordinates $9.845^{\circ} \mathrm{E}$ and $10.329^{\circ} \mathrm{N}$. The area experiences five months of wet season between May and September with the remaining months of the year as dry season. The annual rainfall ranges between $900 \mathrm{~mm}$ and $1000 \mathrm{~mm}$ and a temperature range of $18^{\circ} \mathrm{C}$ to $35^{\circ} \mathrm{C}$. Although in extreme weather conditions, the temperature can be as low as $12^{\circ} \mathrm{C}$ during the harmattan and as high as $40^{\circ} \mathrm{C}$ in March/April periods when the weather is hot.

\subsection{Geological and Hydro-geological Data of Study Area}

The geological formation is composed of crystalline basement complex made up of coarse foliated granite of the older granite suite formation and of Palaeozoic age. Crystalline rocks such as granite and gneisses, when in the unweathered and unfractured state, exhibit very low porosity and are completely impermeable. However, due to prolonged geological activities of chemical weathering, the residues of these rock types are predominantly silty clays and quartz particles, the residue therefore has high porosity, composed of very small interstices. It has been found that even the finest grained clays have only a slight filtration effect on viruses [9], therefore, with such prolonged geological activities, basement complex became favourable to groundwater storage, and can be tapped through boreholes and hand dug wells, monitoring of the groundwater quality is still paramount to ensure the safety of the supply.

\subsection{Limitation of Research}

Limited funds led to the constraint on duration of research.

\section{Materials and Methods}

Domestic Water Samples were collected within the ATBU campus at different locations and these samples serve as representation of the school's groundwater supplies. The sample bottles used for sample collection were sterilized before use, and a visual inspection of the water samples' at source were made as information concerning the sanitary condition of this location is of paramount importance in the assessment of the ground water quality at each location. This research was conducted between June, 2013 and May 2014, water samples were collected in the months of February and March, 2014.

The following water quality parameters were analyzed in the laboratory based on Standard Methods for the Examination of Water and Wastewater [10] towards the determination of the quality of the collected samples:

1. Temperature

2. $\mathrm{pH}$

3. Turbidity

4. Conductivity

5. Total Dissolved Solids (TDS)

6. Chemical Oxygen Demand (COD)

7. Biochemical Oxygen Demand (BOD)

8. Total Hardness

9. Sodium

10. Taste and Odour

11. Potassium

12. Magnesium (hardness)

13. Lead

14. Manganese

15. Arsenic

16. Calcium

17. Copper

18. Zinc

19. Total Bacterial Count (TBC)

\subsection{Water Safety Plan}

The Hazard Analysis of the Ground water source for Domestic use was determined based on the Water Safety Plan using 'Guidelines for Drinking-water Quality [1]. Principles of Water Safety Plans are:

- Preventing pollution at water source;

- Controlled storage;

- Treatment prior to distribution;

- Protection during distribution; and

- Prevention of re-contamination during storage, distribution and handling of drinking water 
Figure 1 presents the framework for safe drinking water based on Water Safety Plan

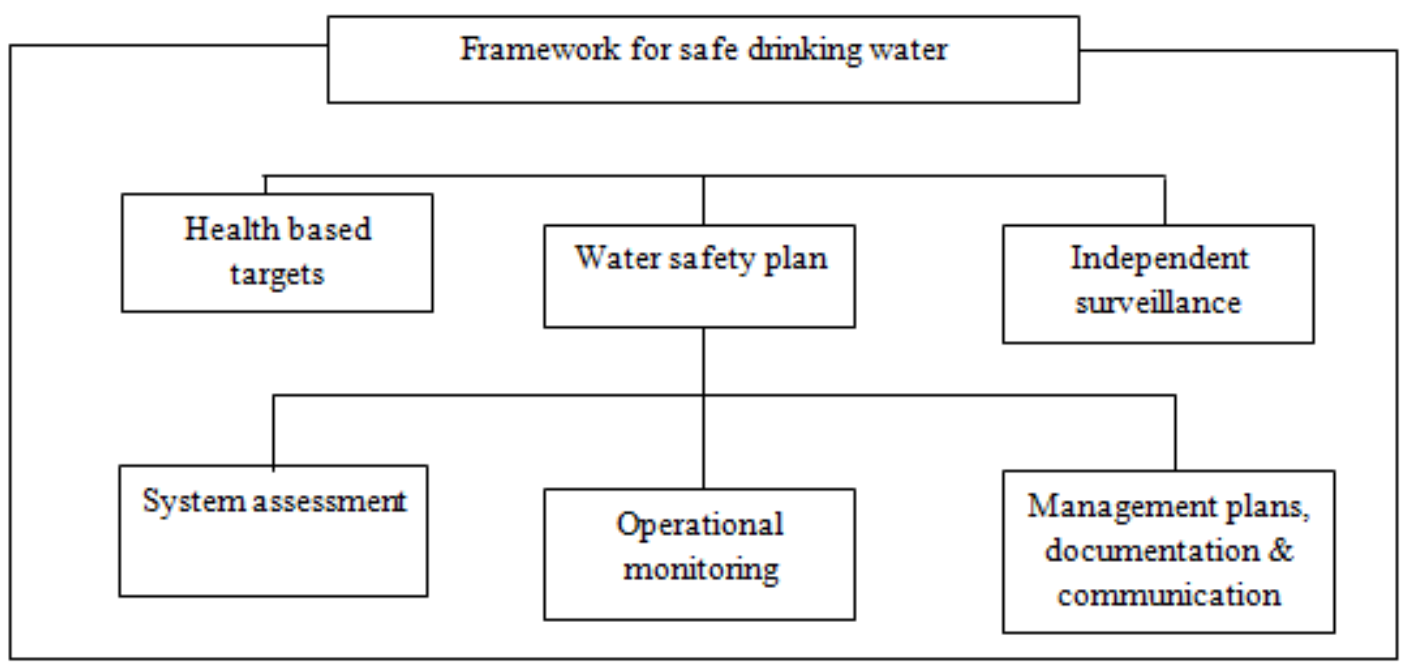

Figure 1. Framework for safe drinking water

\subsection{Hazard Analysis}

Hazards analysis is based on identifying potential risks in systems and preferring solutions to eliminate/ manage the risks accordingly. The following tables are used to monitor the various types and sources of hazards and how they can be identified (from catchment to consumer point of use) [11].

Table 1. Identification of Sources of Hazards

\begin{tabular}{|c|c|}
\hline Hazardous event & Associated hazards (and issues to consider) \\
\hline Poor Water Quality & Contaminants in vicinity of water source \\
\hline Location of septic tanks & Microbial contamination \\
\hline Well/borehole headwork not water tight & Surface water intrusion \\
\hline Flooding around water source & Water Quality compromised \\
\hline
\end{tabular}

Table 2. Typical hazards associated with treatment

\begin{tabular}{|c|c|}
\hline Hazardous event (source of hazard) & Associated hazards (and issues to consider) \\
\hline Any hazard not controlled /mitigated within the catchment & As identified in catchment \\
\hline Power supplies & Interrupted treatment / loss of disinfection \\
\hline Flooding & Loss of restriction \\
\hline Fire/explosion & Loss of restriction \\
\hline
\end{tabular}

\section{Results and Discussion of Results}

Water samples were collected from various locations on the campus as presented in table 3 :

Table 3. Source Locations

\begin{tabular}{|c|c|}
\hline SAMPLE & LOCATION \\
\hline A & Girls' hostel (Borehole pumped into ground tank with rope and bucket system) \\
\hline B & National Centre for Pet. Resource \& Dev. (Borehole with overhead tank) \\
\hline C & Male Hostel Block E (Hand pumped installed on well) \\
\hline D & ICT Centre (hand dug well with rope and bucket system) \\
\hline E & Central Bore hole (Borehole with overhead tank) \\
\hline
\end{tabular}




\subsection{Results}

The laboratory results obtained from the analyzed water samples are presented in table 4 . (The average result from multiple water sampling bottles for each water source is presented).

Table 4. Laboratory Results for Different Sample Locations for Samples A to E

\begin{tabular}{|c|c|c|c|c|c|c|c|c|}
\hline PARAMETER & & $\mathbf{A}$ & $\mathbf{B}$ & $\mathbf{C}$ & $\mathbf{D}$ & $\mathbf{E}$ & NIS & WHO \\
\hline TEMPERATURE & ${ }^{\circ} \mathrm{C}$ & 30.2 & 30.0 & 30.0 & 30.0 & 30.1 & Ambient & Ambient \\
\hline CONDUCTIVITY & $\mu \mathrm{S} / \mathrm{cm}$ & 480 & 750 & 1430 & 340 & 420 & 1000 & 1400 \\
\hline Total DisSolved Solids(TDS) & $\mathrm{mg} / \mathrm{l}$ & 240 & 370 & 710 & 170 & 210 & 500 & 1000 \\
\hline TURBIDITY & $\mathrm{NTU}$ & 0.27 & 0.43 & 1.97 & 0.77 & 0.25 & 5 & 5 \\
\hline PH & --- & 8.2 & 7.5 & 7.1 & 7.5 & 7.8 & $6.5-8.5$ & $6.5-8.5$ \\
\hline COPPER & $\mathrm{mg} / \mathrm{L}$ & 0.02 & 0.10 & 1.77 & 0.02 & 0.02 & 1 & 1.3 \\
\hline ZINC & $\mathrm{mg} / \mathrm{L}$ & 0.23 & 0.35 & 0.31 & 0.24 & 0.32 & 3 & 5 \\
\hline TOTAL HARDNESS & $\mathrm{mg} / \mathrm{L}$ & 90 & 170 & 165 & 80 & 140 & 150 & 500 \\
\hline MAGNESIUM (HARDNESS) & $\mathrm{mg} / \mathrm{L}$ & 2.45 & 8.00 & 7.46 & 1.38 & 2.36 & 50 & 50 \\
\hline COD & $\mathrm{mg} / \mathrm{L}$ & 6.32 & 0 & 3.79 & 4.74 & 0 & 10 & 10 \\
\hline ARSENIC & $\mathrm{mg} / \mathrm{L}$ & 0 & 0 & 0 & 0 & 0 & 0.01 & 0.01 \\
\hline SODIUM & $\mathrm{mg} / \mathrm{L}$ & 14 & 30 & 48 & 10 & 13 & 200 & 200 \\
\hline POTASSIUM & $\mathrm{mg} / \mathrm{L}$ & 0 & 4 & 16 & 6 & 0 & $\mathrm{NA}$ & 55 \\
\hline LEAD & $\mathrm{mg} / \mathrm{L}$ & 0 & 0 & 0 & 0 & 0 & 0.01 & 0.01 \\
\hline MANGANESE & $\mathrm{mg} / \mathrm{L}$ & 0.04 & 0.01 & 0.06 & 0.01 & 0.01 & 0.2 & 0.5 \\
\hline CALCIUM & $\mathrm{mg} / \mathrm{L}$ & 13.2 & 16.0 & 56.4 & 28.1 & 12.9 & $\mathrm{NA}$ & 75 \\
\hline TASTE & --- & $\mathrm{U}$ & $\mathrm{U}$ & $\mathrm{U}$ & $\mathrm{U}$ & $\mathrm{U}$ & $\mathrm{U}$ & $\mathrm{U}$ \\
\hline ODOUR & --- & $\mathrm{U}$ & $\mathrm{U}$ & $\mathrm{U}$ & $\mathrm{U}$ & $\mathrm{U}$ & $\mathrm{U}$ & $\mathrm{U}$ \\
\hline BOD & $\mathrm{mg} / \mathrm{L}$ & 2.8 & 0 & 2.0 & 2.6 & 0 & 6 & 6 \\
\hline TOTAL BACTERIAL COUNT & $\mathrm{Cfu} / \mathrm{mL}$ & 9 & 0 & 0 & 36 & 0 & 100 & 100 \\
\hline
\end{tabular}

$\mathrm{U}=$ Unobjectionable;

$---=$ No Unit;

$\mathrm{NA}=$ Not Available

NIS - Nigerian Industrial Standards

WHO - World Health Organization

The results of the Hazard Analysis are given in Tables 5 to 8.

Table 5. Hazard Event - Poor Water Quality

\begin{tabular}{|c|c|c|c|c|c|c|c|c|c|c|}
\hline \multirow{2}{*}{$\begin{array}{c}\text { Hazard } \\
\text { Event }\end{array}$} & \multirow{2}{*}{$\begin{array}{l}\text { Water } \\
\text { source }\end{array}$} & \multirow{2}{*}{$\begin{array}{l}\text { Associated } \\
\text { Hazard }\end{array}$} & \multirow{2}{*}{ Cause } & \multirow{2}{*}{ Risk } & \multicolumn{2}{|c|}{ Critical Limits } & \multirow[b]{2}{*}{$\begin{array}{l}\text { Corrective } \\
\text { Action }\end{array}$} & \multicolumn{3}{|c|}{ Monitoring } \\
\hline & & & & & $\begin{array}{c}\text { Current } \\
\text { Situation }\end{array}$ & Target & & What & When & Who \\
\hline \multirow{5}{*}{$\begin{array}{l}\text { Poor } \\
\text { Water } \\
\text { Quality }\end{array}$} & A & \multirow{5}{*}{$\begin{array}{c}\text { Contaminant } \\
\text { in Vicinity } \\
\text { of Water } \\
\text { Source }\end{array}$} & $\begin{array}{c}\text { Microbial } \\
\text { Contamination }\end{array}$ & $\begin{array}{l}\text { Low } \\
\text { Risk }\end{array}$ & $\begin{array}{l}\text { Rope and } \\
\text { bucket } \\
\text { system of } \\
\text { abstraction } \\
\text { unacceptable }\end{array}$ & $\begin{array}{c}\text { Protected } \\
\text { Water } \\
\text { Source }\end{array}$ & $\begin{array}{c}\text { Install } \\
\text { motorized } \\
\text { or } \\
\text { handpump } \\
\text { on water } \\
\text { source }\end{array}$ & \multirow{5}{*}{$\begin{array}{l}\text { Water } \\
\text { Quality }\end{array}$} & \multirow{5}{*}{ Weekly } & \multirow{5}{*}{$\begin{array}{l}\text { Designated } \\
\text { Personnel }\end{array}$} \\
\hline & B & & $\begin{array}{c}\text { Not } \\
\text { Applicable }\end{array}$ & $\begin{array}{c}\text { No } \\
\text { Observed } \\
\text { Risk }\end{array}$ & Acceptable & & None & & & \\
\hline & $\mathrm{C}$ & & $\begin{array}{c}\text { High TDS and } \\
\text { Conductivity } \\
\text { levels }\end{array}$ & $\begin{array}{l}\text { Low } \\
\text { Risk }\end{array}$ & $\begin{array}{c}\text { Sanitary } \\
\text { Situation } \\
\text { around } \\
\text { platform } \\
\text { unacceptable }\end{array}$ & $\begin{array}{l}\text { Sanitary } \\
\text { situation } \\
\text { around } \\
\text { water } \\
\text { source } \\
\text { acceptable }\end{array}$ & $\begin{array}{c}\text { Repair } \\
\text { environment } \\
\text { around } \\
\text { water source }\end{array}$ & & & \\
\hline & $\mathrm{D}$ & & $\begin{array}{c}\text { Microbial } \\
\text { Contamination }\end{array}$ & $\begin{array}{l}\text { Low } \\
\text { Risk }\end{array}$ & $\begin{array}{l}\text { Rope and } \\
\text { bucket } \\
\text { system of } \\
\text { abstraction } \\
\text { unacceptable }\end{array}$ & $\begin{array}{l}\text { Protected } \\
\text { Water } \\
\text { Source }\end{array}$ & $\begin{array}{c}\text { Install } \\
\text { motorized } \\
\text { or } \\
\text { handpump } \\
\text { on water } \\
\text { source }\end{array}$ & & & \\
\hline & $\mathrm{E}$ & & $\begin{array}{c}\text { Not } \\
\text { Applicable }\end{array}$ & $\begin{array}{c}\text { No } \\
\text { Observed } \\
\text { Risk }\end{array}$ & Acceptable & & None & & & \\
\hline
\end{tabular}


Table 6. Hazard Event - Septic Tank Location:

\begin{tabular}{|c|c|c|c|c|c|c|c|c|c|c|}
\hline \multirow{2}{*}{$\begin{array}{l}\text { Hazard } \\
\text { Event }\end{array}$} & \multirow{2}{*}{$\begin{array}{l}\text { Water } \\
\text { source }\end{array}$} & \multirow{2}{*}{$\begin{array}{l}\text { Associated } \\
\text { Hazard }\end{array}$} & \multirow{2}{*}{ Cause } & \multirow[b]{2}{*}{ Risk } & \multicolumn{2}{|c|}{ Critical Limits } & \multirow[b]{2}{*}{$\begin{array}{c}\text { Corrective } \\
\text { Action }\end{array}$} & \multicolumn{3}{|c|}{ Monitoring } \\
\hline & & & & & $\begin{array}{c}\text { Current } \\
\text { Situation } \\
\end{array}$ & Target & & What & When & Who \\
\hline \multirow{5}{*}{$\begin{array}{c}\text { Location } \\
\text { of Septic } \\
\text { Tank } \\
\text { from } \\
\text { Water } \\
\text { Source }\end{array}$} & $\mathrm{A}$ & \multirow{5}{*}{$\begin{array}{c}\text { Microbial } \\
\text { Contamination }\end{array}$} & \multirow{5}{*}{$\begin{array}{l}\text { Facility } \\
\text { location }\end{array}$} & \multirow{5}{*}{$\begin{array}{c}\text { No } \\
\text { Observed } \\
\text { Risk }\end{array}$} & \multirow{5}{*}{ Acceptable } & & \multirow{5}{*}{ None } & \multirow{5}{*}{$\begin{array}{l}\text { Location } \\
\text { of New } \\
\text { Sanitary } \\
\text { Facilities }\end{array}$} & \multirow{5}{*}{ Bi-annually } & \multirow{5}{*}{$\begin{array}{c}\text { Designated } \\
\text { Personnel }\end{array}$} \\
\hline & B & & & & & & & & & \\
\hline & $\mathrm{C}$ & & & & & & & & & \\
\hline & $\mathrm{D}$ & & & & & & & & & \\
\hline & $\mathrm{E}$ & & & & & & & & & \\
\hline
\end{tabular}

Table 7. Hazard Event - Well/ Borehole head not Water Tight:

\begin{tabular}{|c|c|c|c|c|c|c|c|c|c|c|}
\hline \multirow{2}{*}{$\begin{array}{l}\text { Hazard } \\
\text { Event }\end{array}$} & \multirow{2}{*}{$\begin{array}{l}\text { Water } \\
\text { source }\end{array}$} & \multirow{2}{*}{$\begin{array}{c}\text { Associated } \\
\text { Hazard }\end{array}$} & \multirow[b]{2}{*}{ Cause } & \multirow[b]{2}{*}{ Risk } & \multicolumn{2}{|c|}{ Critical Limits } & \multirow[b]{2}{*}{$\begin{array}{c}\text { Corrective } \\
\text { Action }\end{array}$} & \multicolumn{3}{|c|}{ Monitoring } \\
\hline & & & & & $\begin{array}{c}\text { Current } \\
\text { Situation }\end{array}$ & Target & & What & When & Who \\
\hline \multirow{5}{*}{$\begin{array}{c}\text { Well/ } \\
\text { Borehole } \\
\text { head not } \\
\text { water } \\
\text { tight }\end{array}$} & A & \multirow{5}{*}{$\begin{array}{l}\text { Surface } \\
\text { Water } \\
\text { Intrusion }\end{array}$} & $\begin{array}{c}\text { Use of } \\
\text { rope and } \\
\text { bucket for } \\
\text { abstraction }\end{array}$ & $\begin{array}{l}\text { High } \\
\text { Risk }\end{array}$ & $\begin{array}{c}\text { Use of } \\
\text { rope and } \\
\text { bucket for } \\
\text { abstraction }\end{array}$ & $\begin{array}{c}\text { Protected } \\
\text { Water } \\
\text { Source }\end{array}$ & $\begin{array}{c}\text { Install } \\
\text { motorized } \\
\text { or } \\
\text { handpump } \\
\text { on water } \\
\text { source }\end{array}$ & \multirow{5}{*}{$\begin{array}{c}\text { Protection } \\
\text { of Well/ } \\
\text { Borehole } \\
\text { head }\end{array}$} & \multirow{5}{*}{ Bi-annually } & \multirow{5}{*}{$\begin{array}{c}\text { Designated } \\
\text { Personnel }\end{array}$} \\
\hline & B & & $\begin{array}{c}\text { Not } \\
\text { Applicable }\end{array}$ & $\begin{array}{c}\text { No } \\
\text { Observed } \\
\text { Risk }\end{array}$ & $\begin{array}{c}\text { Protected } \\
\text { Well/ } \\
\text { Borehole } \\
\text { head }\end{array}$ & $\begin{array}{c}\text { Protected } \\
\text { Water } \\
\text { Source }\end{array}$ & None & & & \\
\hline & $\mathrm{C}$ & & $\begin{array}{c}\text { Not } \\
\text { Applicable }\end{array}$ & $\begin{array}{c}\text { No } \\
\text { Observed } \\
\text { Risk }\end{array}$ & $\begin{array}{c}\text { Protected } \\
\text { Well/ } \\
\text { Borehole } \\
\text { head }\end{array}$ & $\begin{array}{c}\text { Protected } \\
\text { Water } \\
\text { Source }\end{array}$ & None & & & \\
\hline & $\mathrm{D}$ & & $\begin{array}{c}\text { Use of } \\
\text { rope and } \\
\text { bucket for } \\
\text { abstraction }\end{array}$ & $\begin{array}{l}\text { High } \\
\text { Risk }\end{array}$ & $\begin{array}{c}\text { Use of } \\
\text { rope and } \\
\text { bucket for } \\
\text { abstraction }\end{array}$ & $\begin{array}{c}\text { Protected } \\
\text { Water } \\
\text { Source }\end{array}$ & $\begin{array}{c}\text { Install } \\
\text { motorized } \\
\text { or } \\
\text { handpump } \\
\text { on water } \\
\text { source }\end{array}$ & & & \\
\hline & $\mathrm{E}$ & & $\begin{array}{c}\text { Not } \\
\text { Applicable }\end{array}$ & $\begin{array}{c}\text { No } \\
\text { Observed } \\
\text { Risk }\end{array}$ & $\begin{array}{l}\text { Protected } \\
\text { Well/ } \\
\text { Borehole } \\
\text { head }\end{array}$ & $\begin{array}{c}\text { Protected } \\
\text { Water } \\
\text { Source }\end{array}$ & None & & & \\
\hline
\end{tabular}

Table 8. Hazard Event - Flooding around water source:

\begin{tabular}{|c|c|c|c|c|c|c|c|c|c|c|}
\hline \multirow{2}{*}{$\begin{array}{c}\text { Hazard } \\
\text { Event }\end{array}$} & \multirow{2}{*}{$\begin{array}{l}\text { Water } \\
\text { source }\end{array}$} & \multirow{2}{*}{$\begin{array}{l}\text { Associated } \\
\text { Hazard }\end{array}$} & \multirow[b]{2}{*}{ Cause } & \multirow[b]{2}{*}{ Risk } & \multicolumn{2}{|c|}{ Critical Limits } & \multirow[b]{2}{*}{$\begin{array}{l}\text { Corrective } \\
\text { Action }\end{array}$} & \multicolumn{3}{|c|}{ Monitoring } \\
\hline & & & & & $\begin{array}{c}\text { Current } \\
\text { Situation } \\
\end{array}$ & Target & & What & When & Who \\
\hline \multirow{5}{*}{$\begin{array}{c}\text { Flooding } \\
\text { around } \\
\text { water } \\
\text { source }\end{array}$} & A & \multirow{5}{*}{$\begin{array}{l}\text { Water Quality } \\
\text { Compromised }\end{array}$} & \multirow{5}{*}{$\begin{array}{c}\text { Not } \\
\text { Applicable }\end{array}$} & \multirow{5}{*}{$\begin{array}{c}\text { No } \\
\text { Observed } \\
\text { Risk }\end{array}$} & \multirow{5}{*}{$\begin{array}{c}\text { Protected } \\
\text { Well/ } \\
\text { Borehole } \\
\text { head }\end{array}$} & \multirow{5}{*}{$\begin{array}{c}\text { Protected } \\
\text { Water } \\
\text { Source }\end{array}$} & \multirow{5}{*}{ None } & & & \\
\hline & B & & & & & & & & & \\
\hline & $\mathrm{C}$ & & & & & & & & & \\
\hline & $\mathrm{D}$ & & & & & & & & & \\
\hline & E & & & & & & & & & \\
\hline
\end{tabular}

\subsection{Discussion of Results}

From the results presented in table 4 , it is observed that Sample C (obtained from the hand pumped well, Block E of the boys' hostel) contain the highest Total Dissolved Solids (TDS), and of course the highest turbidity and conductivity levels which are $710 \mathrm{mg} / \mathrm{L}, 1.97 \mathrm{NTU}$ and $1430 \mu \mathrm{S} / \mathrm{cm}$ respectively.

The Nigerian Industrial Standards for Drinking Water [12] specifies that the maximum permitted levels of TDS and Conductivity be $500 \mathrm{mg} / \mathrm{L}$ and $1000 \mu \mathrm{S} / \mathrm{cm}$ respectively. In sample $C$, the highest obtained values of TDS and conductivity are $710 \mathrm{mg} / \mathrm{L}$ and $1430 \mu \mathrm{S} / \mathrm{cm}$ respectively, which are slightly higher than the stated standard.

The turbidity and $\mathrm{pH}$ levels range from $0.25 \mathrm{NTU}$ to 1.97NTU and 7.1 to 8.2 respectively with sample $\mathrm{C}$ ranking highest for turbidity and lowest $\mathrm{pH}$ of 7.1. Values of $\mathrm{pH}$ and turbidity obtained in these analyses fall within acceptable 
limits for WHO and NIS specifications.

All other samples met the WHO and NIS guidelines for drinking water in terms of the physiochemical requirements. Among all samples analysed, only samples A and D were found to be contaminated with total bacteria with values of 9 $\mathrm{Cfu} / \mathrm{mL}$ and $36 \mathrm{Cfu} / \mathrm{mL}$ respectively. Sample A, located in front of girls' hostel is a borehole pumped into an underground concrete storage tank. The tank is virtually always opened and the water abstracted using a local fetcher. This explanation also justifies the result obtained for sample $\mathrm{D}$ (a hand dug well within the school's ICTC premise). Since sample $\mathrm{C}$ (hand pumped well behind block $\mathrm{E}$ of boys' hostel) has a concrete apron with vegetation around the apron.

\subsubsection{Hazard Analysis}

Four Domestic Water Source Hazards were identified for analysis:

1. Poor Water Quality

2. Septic Tank Location

3. Well/ Borehole head not Water Tight

4. Flooding around water source

Poor Water Quality: Two (sources B and E) of the five water sources monitored met all the requirements for drinking water, corrective measured were proffered for three sources as seen in table 5. Table 6 presents the hazard analysis for septic tank location in relation to the water sources. All the water sources met the minimum requirement of a distance of at least $30 \mathrm{~m}$ from a water source. Table 7 presents the analysis for unprotected well head. Sources A and D had corrective measures proffered. Table 8 showed the analysis for flooding. All the five water sources were not located in flood zones.

\section{Conclusions and Recommendation}

\subsection{Conclusions}

From the research, it was found that:

1. All sampled water sources met the WHO and NIS standard for drinking water quality.

2. The two water sources with open access for abstraction are high risk sources for contamination.

3. Hazard Analysis proffered corrective measures for water sources with high risks.

4. Need for monitoring of water quality was identified and specific tasks for designated personnel were detailed out.

5. Sanitation around one domestic water source requires improvement to eliminate possibility of contamination of water from the source.

\subsection{Recommendation}

1. Water sources A and D should be upgraded by eliminating current abstraction method.

2. Regular monitoring of domestic water quality should be maintained for all the domestic water sources.

3. Strict adherence to basic environmental sanitation rules should be observed around all the domestic water sources.

4. Installation of sanitation facilities at acceptable distances from domestic water sources should be maintained.

5. Knowledge sharing on 'Water Safety Plans' within the community is recommended as a tool to ensuring safe water supply on the University Campus.

\section{REFERENCES}

[1] WHO. The Guidelines for Drinking-water Quality outlines. Third Edition. Volume 1. World Health Organization. Geneva www.who.int/water_sanitation_health 2004.

[2] UNICEF/World Health Organization. Progress on Sanitation and Drinking Water - 2015 Update and MDG Assessment. WHO Library Cataloging, USA. 2015

[3] Ndububa O. I \& Ndububa E. E,. Design of Sanitation Option for Rural and Semi-Urban Areas in North Eastern Nigeria. International Journal of Environmental Issues. Vol. 1, No. 2. 2003

[4] Rojas, R. Howard, G. Bartram, J. Groundwater quality and water supply in Lima. In: Nash H, McCall GJH, editors. Groundwater quality, AGID Report No. 16. London: Chapman \& Hall. 1995

[5] Omudu, E. A. Sustainable Human Health Excreta Management: a arasitological Perspective on sanitation and Epidemiology of Excreta- related Parasitic Infections. International Journal of Environmental Issues. Vol. 1, No. 2. 2003

[6] Ojoawo S. O, Onyimiebi, S. Environmental Implication of a Municipal Solid Waste Dumpsite Leachate in Contiguous Well. International Journal of Environmental issues. Vol. 5, No $1 \& 2.2007$

[7] Wang, L.D, Mallant, D.P, Maes, N.Y. Radition Waste Management and Environmental Research, American Society of Mechanical Engineers. 2001

[8] Cave, B. And Kolsky P. Groundwater, Latrines and Health, Well Study. Task No: 163. www.polythechnic.edu.na/academ ics 1999

[9] Fourie, A. B. and M. B. van Ryneveld. "The fate in the subsurface of contaminants associated with on-site sanitation: a review." 1995

[10] APHA. Standard Methods for the Examination of Water and Wastewater. AMWA, WWPCF $20^{\text {th }}$ Edition. APHA (American Public Health Association). 1999

[11] Deere D, Stevens M, Davison A, Helm G, Dufour A. Management Strategies. Assessment of risk and risk management for water-related infectious disease. London, World Health Organization, IWA Publishing.2001

[12] Nigerian Industrial Standards. Nigerian Standards for Drinking Water Quality. Standards Organisation of Nigeria, Abuja. 2007 